\title{
Of Boundaries and Revolving Doors: Some Thoughts on Europe, Balkan Cinema and Identity
}

\author{
KAREN VIRAG
}

Recently, I was given a copy of University of Leicester professor Dina Iordanova's impressive new book on Balkan cinema, Cinema of Flames: Balkan Film, Culture and the Media. Among the many issues addressed in this excellent and far-ranging work are cross-cultural representations of the Balkans; the relationship of the Balkans to the European cultural sphere; the siege of Sarajevo, perhaps the most emblematic conflict of the recent wars; the (im)possibility of taking sides in armed conflict; images of women and minorities; and how all these things affect and are affected by Balkan film. The power of Cinema of Flames can be measured in its manifold effects: first, I began a near orgy of Balkan film watching. I had seen some of the films before but was prompted to re-evaluate them in light of a broader cultural and historical awareness. Further, I was inspired to rethink previous assumptions about the meaning of boundaries, belonging and the notion of the state; in other words, to discover what all is in a name.

And I was reminded that east and west are not just points on a compass.

\section{GO EAST, YOUNG WOMAN, GO EAST}

Some time back in the 1980 s, when I told a friend that I was going to Hungary for the summer, she asked with great puzzlement, "Why would you go there?" Her reaction struck me as odd, a trip to Europe in the summer, a pilgrimage to the continent that gave us Michelangelo and Bach being a normal rite of passage for many Canadian university students. It turned out that it was my choice of destination that perturbed her-the suspected rudeness of Eastern Europe could not compare with the known sophistication of Western Europe, and Hungary was not Italy or France, its ancient civilization, wonderful museums, cultured populace, and Bartok and Liszt notwithstanding. In those Iron-Curtain days, the 
Western image of Eastern Europe was of a grey and soulless place, battered and beaten down, full of steroid-overloaded she-men, bread queues, peasants, poverty, and bellicose, irrational people. My friend's misgivings aside, though, I proceeded with my first trip ever to Hungary, with a side-trip to Transylvania, the land of my paternal ancestors. It would be impossible to sum up that summer in a few words but suffice it to say that the trip was a good exercise in demystification (one of the chief benefits of travel and something from which my friend could have benefited). I saw much to admire and, though rural Transylvania was shockingly poor, I have also seen abysmal poverty in North America, notably in New York City and Los Angeles.

So, now that the Cold War has ended and political upheavals have torn down the walls and curtains that demarcated the region, what is the status of the countries of the former Eastern bloc? Are they part of the real (Western) Europe now? For that matter, what is Europe, and is it still usefully divided according to points on the compass? Some former Eastern bloc countries seem to be on their way to a kind of rehabilitation, to use a loaded word, and have been somewhat successful in their quest for their return to the fold of Europe. Others, in particular the countries of the Balkan peninsula, many of whose lands have been savaged by bloody wars in the last decade, are still knocking on a door that no one is opening. So, is Europe a cultural homeland or an exclusive private club? If the latter, what is the password for admission? "Populist democracy"? "Euro"? "Free market"? "McDonald's"? One thing is guaranteed-it certainly isn't "Kosovo." And herein lies the rub. The Balkan countries, specifically those of the former Yugoslavia, turn their gaze westwards, but the West is not looking back. Why? In a wide ranging, cross-cultural discussion, Cinema of Flames provides many thought-provoking answers to this question.

\section{EAST IS EAST AND WEST IS WEST AND NEVER THE \\ TW AIN SHALL MEET}

To a certain extent, mapping and geographical orientation are exercises in power (geo)politics and part of the deliberate and imposed creation of identity. A couple of illustrative cases from our own part of the world are, first, the construction of fences and borders on the North American continent dating back to the arrival of the first whites several hundred years ago. The native population, who had no concept of private ownership of land, must have been both appalled and terrified as the new arrivals gradually made their way across the frontier and began marking off parcels of prairie land with barbed wire (the first iron curtains?). And, second, the appearance, every few months or so, of an article in a newspaper 
somewhere suggesting, with some accuracy perhaps, that Alberta has more in common historically, culturally and economically with the American West than it has with the industrial East of Canada, to which it is tied by the somewhat unnatural and arbitrary $49^{\text {th }}$ parallel. Further, the very terms east and west are loaded: the former often being imaginatively associated with negative traits; the latter with whatever is morally and culturally superior-us, in other words. ${ }^{1}$ (And though we couldn't navigate without them, east and west imply that there is a centre, a somewhat illogical notion on a round earth. East, or west, of what?)

In any case, Europe has been no less subject to this imaginative mapping. According to Larry Wolff, the development of an anthropological perspective of Eastern Europe occurred during the Enlightenment and its mapping of civilization vs. barbarism (Wolff 1994). That is, Eastern Europe was an invention, and "[t]he work of invention lay in the synthetic association of lands, which drew upon both fact and fiction, to produce the general rubric of Eastern Europe. That rubric represented an aggregation of general and associative observations over a diverse domain of lands and peoples" (356). In other words, Eastern Europe, though it obviously consists of actual countries, is a cultural construct, the east (and its negative ties to non-Caucasian people, the Ottoman empire, decadence and Islam) purposely set into opposition to the west (and its positive ties to Caucasians, the Austro-Hungarian empire, probity and Christianity).

For the modern day Eastern European, Western Europe signifies both a desired state of being and a cultural home. Iordanova identifies a scene from Istvan Szabo's examination of mores during the twilight of the Austro-Hungarian empire, Colonel Redl (1985), as emblematic of the importance of this belonging. In the scene, the young Redl, a child of a mixed Ruthenian, Ukrainian and Hungarian family that has fallen on hard times, goes to the home of his aristocratic Hungarian friend. During dinner, he is told that he should learn French because it is just as important as learning to ride a horse-and from then on the film is "about admissibility, and about coming face to face with the European" (Ioradanova 2930). This desire to engage with the Western European on what the Eastern European considers common ground becomes one of the many themes of the cinematic practice of the last decade in the former Yugoslavia.

The word Balkans refers to a large peninsula and a mountain range in southeastern Europe. According to the Canadian Oxford Dictionary, the cognate balkanize means to divide a country into small, mutually hostile units-not exactly a ringing endorsement for the region. The word Europe, on the other hand, has very different connotations (in a frivolous aside, an episode of the Seinfeld tvshow has the title character, a young Jewish New Yorker, taking up the practice of carrying a leather bag. His friends mockingly call it a purse. Embarrassed and 
feeling emasculated, he defends himself, shouting "It's not a purse. It's European!'). In other words, Europe stands for elegance, but also for all the values that we hold dear; it is "the cultural and socio-economic entity which overlaps approximately with the values that are believed to provide the basic principles for cultural and social life ... democracy, freedom of expression, free speech, respect for human rights, individualism. But most of all it is synonymous with prosperity and power that ensure respect" (Iordanova 31). That is, Europe is more than fashion-it is refinement and sophistication, efficiency and order, a cultivated rosebush in the overgrown jungle that is the rest of the world.

Yet even a cursory examination of historical maps will show that Europe is not a fixed entity. Borders change rapidly as wars rage and empires rise and fall. A friend's father lived in Poland and Russia — without changing addresses. The land of my own paternal Hungarian ancestors is now part of Romania. All of this change inevitably leads to the problems of inclusion and exclusion, and shifting national allegiances, not to mention nationalist tensions. Geographically the Balkans are part of Europe, and national histories and ideologies, which depict the area as the bridge between the Occident and the Orient, re-enforce this sense of belonging (Iordanova 32). ${ }^{2}$ Culturally, citizens of the Balkans feel an innate connection to Europe-a Muslim Sarajevan character in Shot Through the Heart, an $\mathrm{HBO}$ production, when faced with the possibility of a civil war, exclaims, "This is Sarajevo, not Somalia. We are Europeans for God's sake!" Instead, Sarajevo, like Beirut, "became a city-martyr" (Iordanova 235). Likewise a character from Boro Draskovic's Vukovar fervently cries that the world won't let Yugoslavia descend into chaos-in actuality, that city was ruthlessly reduced to utter rubble by Serbian forces. Countless other actual events of the Balkan upheavals in the last decade showed how wrong these fictive protestations were, yet Europe remained almost passive about the fate of the area, even when it was revealed that concentration camps had made their ugly return to European soil for the first time since the Second World War. 3

The past ten years have seen overtures on the part of many former Eastern bloc countries to return to the European fold. Poland, the Czech Republic and Hungary have joined NATO, and all have applied to become part of the European Union (EU). Iordanova notes that Slovenia and Croatia in particular do not want to be associated with the Balkans and their governments have issued state documents to this effect (Iordanova 34). This wish to avoid identification with the Balkans signifies a number of things: the perceived superiority of Western Europe, a renunciation of any ties to the Orient (and of Islam), a valorization of Catholicism, a renunciation of former neighbours and countrymen, a rising sense of national identity and a reorientation of the gaze towards the 
West. In the broader picture, the very names Eastern and Central Europe have been reconceptualized, and no less than the American army now considers the former category outdated: the correct terms are now Central Europe and the Balkans (Iordanova 41-42). So, the former Eastern bloc has been rehabilitated; the Balkans are still on the periphery.

\section{IF YOU'RE NOT WITH US, YOU'RE AGAINST US}

In these days of polarized politics with wanted-dead-or-alive frontier justice being foisted on the world by the Bush administration in its so-called war on terrorism (how could any reasonable person be in favour of terrorism?), the questions arise: Can one not take sides? Is refusing to take sides actually taking a side? What responsibility do we have to our families, friends and culture and how does that responsibility relate to personal ethics? For his stated desire in the early 1990 s to stay unaligned, Bosnian Muslim director Emir Kusturica was harshly criticized and labelled a "Yugo-nostalgic," a category that described a number of intellectuals who refused to take sides (Iordanova 121). Kusturica, the best known of the exYugoslavian filmmakers, has made a number of films which have garnered international attention, among them When Father Was Away on Business (1985), The Time of the Gypsies (1989), Black Cat, White Cat (1998) but his most (in)famous work is the controversial Underground, a complicated and highly politicized film (the latter trait always difficult for North American audiences). Though it won the Palme d'Or at Cannes in 1995, Underground caused an international storm of criticism about Kusturica's political beliefs and alliances that eventually prompted him to announce his retirement from filmmaking (an announcement that was later retracted.)

Underground follows the life of three protagonists-Marko, a cunning opportunist; Natalia, an equally opportunistic actress; and Blacky, a bellicose fool—and it mirrors events in Yugoslavia's history. In part one, "War," it is April 6, 1941, and the Nazis are bombing Belgrade. Marko leads a group of friends and family to a large cellar for shelter, but does not enter himself. Instead, he and Blacky go above ground and commit a series of robberies, which they pretend are acts of patriotism, then Marko convinces Blacky to return to the cellar while he remains above ground. In part two, entitled "Cold War" and set in the early 196os, Marko has become a beloved national poet and has married Natalia. And though it is over 20 years later, the people are still hiding in the cellar. Occasionally, Marko plays recordings of battle sounds to them as proof that the Nazis are still in power and that it is too dangerous to surface. Meanwhile, he and Natalia use them as slave labour to manufacture arms that Marko sells on the black market. During 
a raucous underground wedding, the walls of the cellar crumble and reveal a series of tunnels running to the West in which streams of people are trying to escape. Blacky and his son go above ground but the son is killed and Blacky is captured by the police. Meanwhile Marko blows up the house and the armaments factory. The third part, also called "War," is set in the early 199os on a battlefield in an undisclosed location. Marko and Natalia are still immoral black marketeers, selling arms to whoever will buy them. Blacky is a paramilitary commander. Marko's long lost brother appears. He realizes what Marko has done and beats him to death; the military forces shoot Natalia and set the two bodies on fire. Blacky bangs his head against an upside down crucifix as he watches the bodies of his former friends burn.

All does not end there, however; the film contains a utopian epilogue-a wedding attended by all the dead protagonists. As they celebrate on a beautiful bright day on the shores of the Danube, so much in contrast to the pervasive darkness of the rest of the film, the bit of land they are on breaks off, and as they continue to dance and sing, their little island floats away down the river to an unknown destination. Iordanova tells us that this final scene was the main image that "screenwriter Kovacevic and Kusturica had in mind all along ... the authors were determined to use this particular scene as the defining metaphor for Yugoslavia" (Iordanova 114). According to Kusturica:

They go away without knowing what has happened to them. That is the way of the Balkan people. They never rationalize their past. Somehow the passion that leads them forward is not changed. I hope some day people may find better ways to use the passion they have so far persistently used to kill one another. (Kusturica in Robinson, 1996, 12, as cited in Iordanova, 115)

Kusturica was roundly criticized for abandoning Sarajevo when it needed him most, for producing propaganda for the Serbs in the form of Underground and for playing the enfant terrible, whose artistic nature imbues him with a special moral code that absolves him of moral responsibility, rather like the one on display in The Wonderful, Horrible Life of Leni Riefensthal (1993). Iordanova admits that Underground could not have been made anywhere but Belgrade, but she also asserts that "[m]aking movies in Belgrade when you have a choice of making them somewhere else is taking sides" (129).

The issue of partisanship is fictively explored in Milchovi Manchevski's Before the Rain. In this film, Aleksander is a Macedonian photographer who has been living in London. On assignment, he had a brutalizing experience in which a man is shot simply to provide him with a photograph. Though he didn't will the shooting, he profited from it and has done much soul-searching about his culpability in the incident and about what it means to take sides. He decides to 
return to his village in Macedonia but finds it much changed. Whereas previously its Orthodox and Muslim populations co-existed peacefully, the village is now divided and violence is brewing. In a non-linear narrative that only comes together at the end, an Albanian Muslim girl, the daughter of an old friend, kills an Orthodox Macedonian relative of Aleksander's with a pitchfork when he tries to rape her. Alexander discovers that his family is holding the girl and is planning to kill her. He will not have any part of this barbarity and tries to help her escape. His family shoots him. The girl manages to get away but is later killed by her family when she tries to leave with a young Macedonian Christian, Aleksander's nephew.

Much of the controversy that erupted in Europe over Underground and, to a lesser extent, Before the Rain is probably lost on North American audiences, which have at best a vague knowledge of the intricacies of Balkan politics, and which are also quite likely to consider the characterization of Balkan events as uncontrollable and brutal to be perfectly natural and accurate. This is confirmed by Iordanova, who notes that Western audiences perceived Underground as "a gargantuan metaphor of the messy state of Balkan affairs rather than as a finely crafted propagandistic insinuation that would work in favour of one of the warring sides" (118). She also comments on the basic level of ignorance of Western critics: "Underground was consistently described by Western critics as a Bosnian movie, even though the film was a French, German and Hungarian production, shot in Prague, Belgrade and Plovdiv, set in Belgrade, dealing with Serbs and Croats, and not touching directly on anything Bosnian" (118). Many European critics (e.g., Cerovic 1995) saw Underground as a capitulation to and collaboration with Serb aggression, which was especially embittering because Kusturica is from Sarajevo, the city that came to symbolize the worst excesses of Serbian aggression. This criticism was made more pointed by the fact that the film was made at a time when Serbia was largely viewed as the aggressor in the wars that ensued after the breakup of Yugoslavia (Iordanova 116).

For his part, Kusturica disavowed any responsibility other than that of realizing an artistic vision (as Klaus Maria Brandauer's apolitical Nazi-collaborating character shouts at the end of Szabo's Mephisto, "What do you want from me? I am only an actor!"). Iordanova informs us that, in a strange (and, one hopes, unintentional) parody of actress Sally Field's embarrassing 1985 Oscar acceptance speech when she exclaimed tearfully, "You like me. Right now, you like me!", Kusturica accepted his 1995 Palme d'Or by saying, "There is only one reason for me to make movies. To be loved by you?" (thus sowing, as did Field, the seeds of animosity). Still, that some artists claim to have a special right to be morally and ethically disengaged in their quest to realize their artistic vision is not a new 
notion. Though many of Kusturica's peers simply refused to talk about it, Srdjan Dragojevic, director of Pretty Village, Pretty Flame, publicly defended Kusturica, saying that he, Kusturica, had done the right thing, that it is not necessary to choose one side in a conflict. "If you do that," he said, "you stop being an artist" (cited in Iordanova, 128).

\section{HAVE SEEN THE OTHER AND HE IS US}

Though the notion of the "other" is well-worn among academics, it is nevertheless a useful one, and it lies at the heart of much of what Iordanova says about the perception of the Balkans in the West. The creation of a state of Otherness implies a number of things: a certain physical distance; an oppressed gaze and a privileged one; a difference in economic standards; a means to dehumanize (this can come in the form of the other culture being represented as less advanced, less sophisticated, physically unattractive, descended from the wrong group); and a difference in language hierarchy, for example a Slavic language in contrast with a Romance or Germanic language (as we saw in Colonel Redl). And the collaboration of those from the Other side can't hurt either. For Slavoj Zizek, this is what both Kusturica and Manchevski do in their films. According to him they exhibit a case of "balkanism"; that is, they provide a timeless space, a kind of tabula rasa upon which the West can, à la Said, project its imaginative myths:

Together with Milche Manchevski's Before the Rain, Underground is the ultimate ideological product of Western liberal multiculturalism: what these two films offer to the Western liberal gaze is precisely what this gaze wants to see in the Balkan war-the spectacle of a timeless, incomprehensible, mythical cycle of passions, in contrast to the decadent and anemic Western life. (cited in Iordanova 130)

There is no doubt that many structures uphold and perpetuate mythical concepts of Others and that the group in question often helps to popularize negative stereotypes. These structures can be as sophisticated as non-linear-narrative arthouse films made by accomplished filmmakers, or as simple as urban-myth-like stories and jokes. I recently saw a television interview with an elderly Hungarian man who said that if one enters a revolving door ahead of a Hungarian, the Hungarian always manages to come out ahead. In other words, Hungarians are pushy, sneaky and untrustworthy. A close Italian-Canadian acquaintance exhibits much pride when his Italian heritage is linked with the Mafia; for him, it means that his "culture is to be taken seriously." It is not uncommon for people to repeat, build upon, embellish and become complicit with negative stereotypes about themselves, as though self-denigration helps them claim a place in a valorized 
narrative, even though it is not their own. Another Italian, Antonio Gramsci, gave this a name, of course: hegemony.

For Iordanova, whether or not Underground is pro-Serbian propaganda is up for debate. What is more problematic is that, with Underground, Kusturica performs the moral equivalent of the Hungarian-in-the-revolving-door trope because he "ultimately attributes [the immorality of the characters in Underground] to impaired moral standards innate in the Balkan social character, an approach which is nothing else but a refined version of the primordialist argument, according to which the passions being played out in the Balkan conflict are of a pre-moral level" (119).

I must admit that I found Underground mesmerizing. When I first saw it, I had heard of Kusturica, of course, but knew little about him. It was not until I began reading critical reactions from the European critics and Iordanova that I recognized the political implications of the film, which, for a Canadian with an interested layman's knowledge of the Balkans, seemed to be largely about the problems inherent in a repressive communist regime. At that time, I was unaware that Kusturica was a Bosnian Muslim, but if the author is merely a cultural construct it really shouldn't matter, should it? Clearly it does in this case, nicely illustrating that the author (or director) isn't so dead after all. ${ }^{4}$

As for Before the Rain, I am tempted to view it as a cautionary tale, not meant to specify a particular group or region but to show the tragedies, small and large, that arise from ethnic conflict, which can happen anywhere on earth. Indeed, Manchevski's stated purpose in making the film was to explore violence and intolerance and not to point to Macedonia in particular (Iordanova 78). And in the face of the prevalence of violence in the world, it seems a bit unjust to ascribe a greater capacity for it to the Balkans, as though genocide were something the Serbs or Croats thought up. The names Cambodia, Rwanda, Armenia and the Spanish Inquisition happen to spring to mind here, not to mention the thought that not so long ago one of the great cultures of Western Europe tried to make soap out of an entire race of people. As the well-travelled writer Paul Bowles, who knew a thing or two about violence and being the Other, noted, "As far as I can see, people from all corners of the earth have an unlimited potential for violence" (from an interview in Paris Review, 1981, cited in Prose, 62).

\section{FROM THE OUTSIDE LOOKING IN}

Many Balkan films (for example, Zorba the Greek (1964); Ulysses' Gaze (1995), Welcome to Sarajevo (1997)) show outsiders entering the Balkan space and reacting to the unfathomable, slightly uncivilized people they meet there. This view of the 
visiting foreigner, expressed through selected images, has helped to shape Western attitudes towards the Balkans, thus working against the full acceptance of the Balkans into the European space. The Balkans are frequently represented as exotic, dark, barbarous, untamable, and cultural and media images reinforce these attitudes. Think of the enduring strength of vampire mythology so closely associated with Eastern Europe; filmically, think of the enigmatic, wild character of Zorba in Zorba the Greek, who acts as the perfect foil to the curious, yet rational, Englishman. Though based on a 1946 novel by Greek writer Nikos Kazantzakis and a script by Cypriot Michael Cacoyannis, the film version of Zorba the Greek departs from the novel and is essentially about an outsider's view of the wild and passionate Balkan character. All of Zorba's actions are filtered by the Englishman, who, in the end, though greatly affected by his relationship with Zorba, nevertheless returns to a certain future in England, while the character Zorba is almost forgotten, having acted entirely as a cipher for the other.

Welcome to Sarajevo, perhaps the best known Western commercial film about the Balkans, concerns a British journalist in Sarajevo who, though he tries to remain impassive, takes pity on a young girl he meets in an orphanage and takes her back to England to live with his family. When he later learns that the girl's mother is actually still alive, he returns to Bosnia to arrange for her adoption. At first, the mother (who must perforce abjectly admit to being a bad mother in the best politically correct tradition) refuses to sign the adoption papers. Finally, she phones her daughter in England. The girl refuses to speak Bosnian; then, in a final break with her downtrodden homeland, she tells her mother, "This is my home." The mother immediately signs the papers. Iordanova suggests that, instead of empathizing with the characters in this film, Welcome to Sarajevo keeps the "viewer alienated and relies on Brechtian type of rational moral judgement rather than on mechanisms of identification of compassion" (240). And, certainly, a film that centres around foreign journalists in a war-torn country both impairs an audience's ability to empathize with those who are really suffering and privileges the story of those who are not.

Though Welcome to Sarajevo is problematic in its simplifying of complicated political situations, its Westerner-to-the-rescue ethos and its blatant grab for commercial appeal, I maintain that there is often value in seeing oneself through others' eyes-it is one of the benefits of travel, surely, and also one of the functions of psychologists and counsellors, who provide a stranger's dispassionate view to cast new light on others', often too introspective, often obscure, motivations. And the Other can do much to illuminate and to universalize our own particular problems. A case in point is Ulysses' Gaze, Theo Angelopoulous's masterful 1995 work shows a Greek-American played by Harvey Keitel, returning 
to Greece in search of some early film footage by the legendeary Manakis brothers. His quest leads him in a kind of timeless, placeless wandering through the Balkans, where he ends up in war-torn Sarajevo. In Ulysses' Gaze, "nostalgia is meaningless, and all that remains is the longing for something that is impossible to attain. In the context of this existential pessimism, Balkan troubles are seen as problems of the world, as part of the tiresome recognition of its deterioration" (Iordanova 106-07).

\section{D E N T I T É F I X E}

So, then, who is allowed to represent and talk about whom? Can we only talk about ourselves? If so, doesn't this suggest that there is a correct point of view? Can non-native W. P. Kinsella really write about First Nations' issues? Can men truly represent women? Can Jews speak from a Palestinian point of view and vice versa? Can whites make films about blacks? (Spike Lee doesn't think so). Can, should, a Bosnian Muslim speak for and about Serbs? These questions lead one to ponder the notion of identity and its fixedness. A common misunderstanding of poststructuralist theory is that everything from gender to identity is a construct and nothing has any meaning. If this were true, theorists would be doing a great disservice to people killed in wars, which are definitely not constructs, and, further, would be denying people's emotional and spiritual attachments. It would be far too easy an out and not a very useful way to look at national, racial or religious conflicts. Despite what many undergraduates believe, theory is not our enemy; rather, we should use its insights to illuminate and reveal processes of control and identity formation, which are at constant work. These processes include many things: forms of government, class structure, economic forces, expressions of popular culture, and history, the last being one of the more problematic as it entails the making of defining national myths and is so easily manipulated, so easily burned, banned and rewritten. Living in a young country full of many immigrants, I have relatively few national historical signposts that help me understand who I am, no big defining battles for independence, though there is the war of 1812 , which Canadians often invoke in a kind of manufactured 'I-am-Joe-and-I-am-Canadian' nationalist manifesto. People in more ancient cultures have much more myth-making to contend with. But, no matter where one is, the manipulation of history and national mythologies has long been an effective way for regimes to manufacture specific actions, thought and consent, to typecast people in their own minds with a particular, unique and fixed identity. Yet, considering identity as a fixed, essential quality can lead to deep-seated personal and national mythologies that allow no room for self-criticism, and that, 
in hearkening back to a time that never was, petrify history and solidify character. In the case of the Balkans, and Serbia in particular, the battle of Kosovo in 1389, a date often hailed as a turning point in the creation of the Serbian state, seems to be an event that has helped establish a notion of a fixed Serbian identity. As Bakic-Hayden notes, the problem is that " $\mathrm{t}] \mathrm{he}$ implication is that the 'real' identity of persons or groups is to be found in the pre-Yugoslav past" (923). The notion of a fixed historical identity, then, is another way of creating a voiceless, dehumanized Other, denying dissention, marginalizing minority groups and stifling cultural development.

Very often the result of this is war.

\section{THE CIRCLE IS NEVER ROUND}

This paper began by posing some questions about what it means to be part of Europe and discussing the boundaries of that continent, which, with the expansion of the EU, could change from day to day. A recent National Post article (March 23, 2002) reports that the new country of Serbia and Montenegro (which was the remnant of what was left of Yugoslavia after the recent wars) expects to be part of the EU in "just a matter of time" (Vincent, B1) - though the report also notes that the EU used the same carrot-and-stick tactic last year, promising quick integration to Macedonia, but that country is no closer to belonging than it was. Europe would indeed seem to be the promised land for many of the perhaps not so formerly Eastern countries; nevertheless, many Balkan citizens in the diaspora, like Iordanova, for example, who lives in London, feel that they gave up their home for a safety net of Western liberalism, which then turned into a sham. For them, there is no utopian epilogue. As Iordanova says, "growing disillusionment with this new sphere of belonging resulted in the solitary detachment in which most of us live now. What seemed to be an aftermath of Bosnia turned into a continuation of the Balkan ordeal" (Iordanova 282).

I suppose that Otherness can follow us no matter where we go.

I think back occasionally to my skeptical friend, who couldn't believe that I wanted to go to Hungary for the summer. I hope that she was able to do some travelling in her life. I realize, though, that she was probably right to be so dubious about Eastern Europe and Hungarians. You see, Hungarians are a barbaric people, descended from Asians and Attila, who invaded Europe in A.D. 900, and we all know how bad he was. Another name for them was Uigurs or Ugrians, which, with the addition over the years of a few other letters, became Hungarian. Because these savages were so bloodthirsty and so feared-they were known to eat the babies of their enemies, roasted on the end of pitchforks, and they 
apparently had very bad personal grooming habits-Uigur became the ogre, which is still the word used for a horrible man-and-woman-and-baby-and-pet-eating monster in many languages.

Or so the apocryphal story, probably penned by some Enlightenment wonk, goes.

In other words, I hope she got to go to Eastern Europe for some rest and deconstruction

\section{B I B L I O G R A P H Y}

Bakic-Hayden, Milica. "Nesting Orientalisms: The Case of the Former Yugoslavia." Slavic Review 54 (Winter 1995): 917-31.

Cerovic, Stanko. "Canned Lies." August 1995. Available online at www.barnsdle.demon.co.uk/bosnia/caned.html

Drakulic, Slavenka. Balkan Express: Fragments from the Other Side of the War. London: Hutchinson, 1993.

_. Cafe Europa, Life After Communism. New York: W. W. Norton \& Co., 1996.

Human Rights Watch. "The Fall of Srebenica and the Failure of U.N. Peacekeeping." Publications 7.13 (October 1995) www.hrw.org/summaries.s.bosnia9510.html.

Gerolymatos, Andre. The Balkan Wars: Myth, Reality, and the Eternal Conflict. Toronto, On: Stoddart, 2001.

Horwitz, Tony. "Balkan Death Trap: Scenes from a Futile War." Harper's (March 1993). 35-45.

Iordanova, Dina. Cinema of Flames: Balkan Film, Culture and the Media. London: BFI, 2001.

Klein, Andy. "Killing with Kindness." The Los Angeles New Times, March 8, 2001. Available online at www.newtimesla.com/issues/2001-03-08/film2.html

Lukacs, John. "The End of the Twentieth Century: Historical reflections on a misunderstood topic." Harper's (January 1993): 39-58.

Prose, Francine. "The Coldest Eye: Acting Badly Among the Arabs." Harper's (March 2002): 6065.

Robinson, David. "A Tunnel Vision of the War: An Interview with Emir Kusturica." The Times, March 5, 1996.

Vincent, Isabel. "A 'Freak' State is born: Yugoslavia's replacement is a formula for disaster, critics say." The National Post, March 23, 2002, p B1.

Wolff, Larry. Inventing Eastern Europe: The Map of Civilization on the Mind of the Enlightenment. Stanford, Calif: Stanford University Press, 1994.

\section{F I L M S}

Before the Rain. Dir. Milcho Manchevski. Aim Productions, Noe Productions and Vardar Film, with the participation of British Screen and the European Co-Production Fund, 1994.

Colonel Redl. Dir. Istvan Szabo. MOKEP-Kerszi, Mafilm Studio Objektiv. Manfred Durniok Produktion, ZDF und ORF, 1985.

Mephisto: ein Film. Dir. Istvan Szabo. Mafilm, Studio Objektiv in Zusammenarbeit mit der Manfred Durniok Produktion für Film und Fernsehen, dem HR und ORF, 1981. 
Shot Through the Heart. Dir. David Attwood. HBO Studios, 1998.

Underground. Dir. Emir Kusturica. Ciby 2000 (Paris), Pandora Film (Frankfurt), Novo Film (Budapest), Komuna, Tschapline Films, RTV, Serbia, 1995

Ulysses' Gaze. Dir. Theo Angelopolous. Paradis film, La Generale d'Images, La Sept Cinema, Canal +, Basic Cinematographica, Instituto Luce (RAI), Channel 4, Tele München, Concorde Films, Herbert Kloider, Eurimages Fund of the Council of Europe, 1995.

Vukovar: Poste Restante. Dir. Boro Draskovic. Dan-film Corporation, Limasol, Ministarstvo za Republike Srbije, Steven North SAD, Dante Palladina, Italia, 1994.

Welcome to Sarajevo. Dir. Michael Winterbottom. Miramax, 1997.

The Wonderful Horrible Life of Leni Riefenstahl. Dir. Ray Muller. Kino, 1993.

Zorba, the Greek. Dir. Michael Cacoyannis. Twentieth Century Fox, 1964.

\section{E N D N O T E S}

1 Though this discussion is primarily about Europe, the terms West and Western generally refer to the industrialized nations of Western Europe, as well as the United States and Canada.

2 Normally the Balkans refer to Bulgaria, Macedonia, Serbia and Montenegro, Bosnia and Herzegovina, and Albania. According to Iordanova, "countries such as Croatia, Slovenia, Greece, Romania, Moldova and Turkey are also 'Balkan' in a number of elements of their history, heritage and self-conceptualisation, even though some of them may be, for a variety of reasons, positioned differently in the Western imaginary" (Iordanova 6). Iordanova goes on to note that, in her schema, the Balkans refers not to a geographical concept but to a cultural entity, "widely defined as shared by Byzantine, Ottoman and Austro-Hungarian legacies and by the specific marginal positioning of the region in relation to the western part of the European continent."

3 European indifference is perhaps best exemplified by the massacre of thousands of civilians in the Bosnian town of Srebrenica, with UN forces apparently complacently standing by, unwilling to heed requests for help even from their own forces within the town. (www.hrw.org/summaries.s.bosnia9510.html).

4 My most recent glimpse of Kusturica was in The Widow of Saint-Pierre (La Veuve de SaintPierre, 2000). Set on the French island of Saint-Pierre, located off the coast of Newfoundland, the film is set in 1849 and centers on a progressive couple, played by Daniel Auteuil, the military commander of the island, and his wife, played by Juliette Binoche. In the opening scene a couple of drunken hooligans, one of whom is played by Kusturica, commit a senseless murder. The character played by Kusturica is sentenced to die by the guillotine (or veuve, an old French word for guillotine), but there isn't one on the island, so they must send for one from France. In the meantime, the kindly commander's wife becomes a mentor to Kusturica's rough character, who transforms himself into a paragon of virtue. Eventually, after many good deeds he becomes a beloved figure on the island. After many months, the guillotine finally arrives and the Kusturica character, so good is he, actually helps bring it ashore because he doesn't want to cause work for others. At this stage, the commander refuses to go ahead with the execution, thus leading to his own execution in France, to where he is dismissed, and Kusturica has his head chopped off (rather, the character he plays does). One critic, Andy Klein, writing in the Los Angeles New Times, noted that Kusturica's on-screen presence and charisma are part of what makes 
us accept the rapid change in the townspeople's attitudes towards the reformed murderer. Clearly, this charisma failed him with the critics of Underground, and his subsequent film, Black Cat, White Cat (1998), was universally panned. 